\begin{tabular}{|l|l|}
\hline 2. To: (Receiving organization) & 3. From: (Originating Organization) \\
300 Area Cog. Engineer Group & 300 Area Cog. Engineer Group \\
\hline 5. Proj./Prog./Dept./Div.: & 6. Design Authority/ Design Agent/Cog. \\
324 BLDG. B-Ce11 Clean Up & G.E. Dixson \\
\hline
\end{tabular}

\section{Originator Remarks:}

Specification prepared to give guidance on desired

attributes for movable manipulator for clean up of B-

Cell and potentially other 324 Building hot cells.
11. Receiver Remarks: 11A. Design Baseline Document? [] Yes [X] No $\mathrm{NA}$
4. Related EDT No.:

NA

7. Purchase Order No.:

NA

9. Equip./Component No.: 324-MAT-MAN-001

10. System/Bldg./Facility: MAT/324/B-CELL

12. Major Assm. Dwg. No: :

NA

13. Permit/Permit Application No.: NA

14. Required Response Date: $6-5-98$

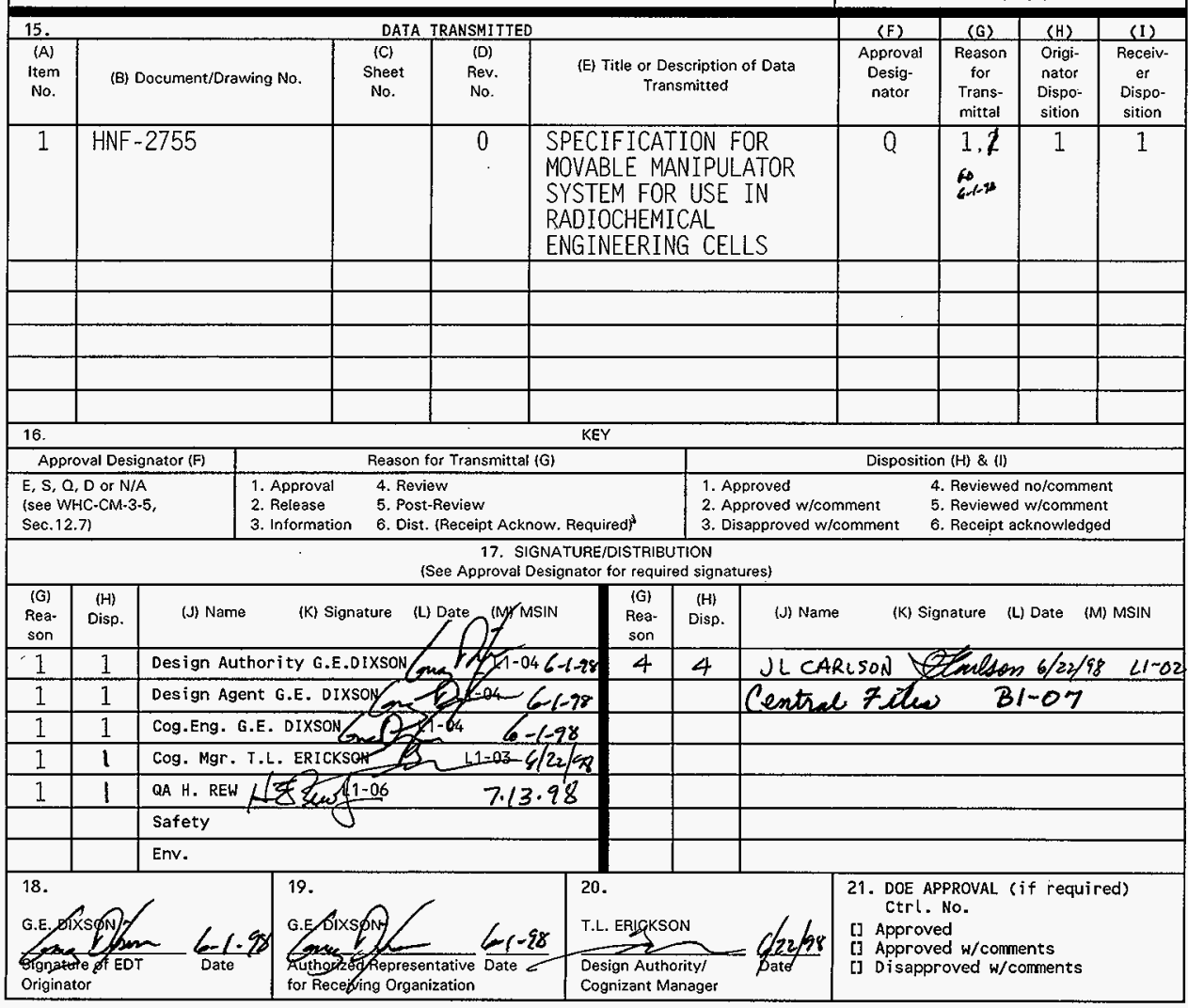




\title{
SPECIFICATION FOR MOVABLE MANIPULATOR SYSTEM FOR USE IN RADIOCHEMICAL ENGINEERING CELLS
}

\author{
G.E. Dixson
}

B \& W Hanford Company, Richland, WA 99352

U.S. Department of Energy Contract DE-AC06-96RL13200
EDT/ECN: 616485
Org Code: 19210
BQR Code: EN 7002010
UC: $506,46-2000$
Charge code: K4M4L
Total Pages: 12

Key Words: 324 Building, Radiochemical Engineering Cells, movable. manipulator

Abstract: This specification prepared to identify requirements for a movable manipulator for use in B-Cell and the REC Airlock at 324

Building. This manipulator could also be used in other hot cells at the 324 Building.

TRADEMARK DISCLAIMER. Reference herein to any specific commercial product, process, or service by trade name, trademark, manufacturer, or otherwise, does not necessarily constitute or imply its endorsement, recommendation, or favoring by the United States Government or any agency thereof or its contractors or subcontractors.

Printed in the United States of America. To obtain copies of this document, contact: Document Control Services, P.0. Box 950, Mailstop H6-08, Richland WA 99352, Phone (509) 372-2420; Fax (509) 376-4989.
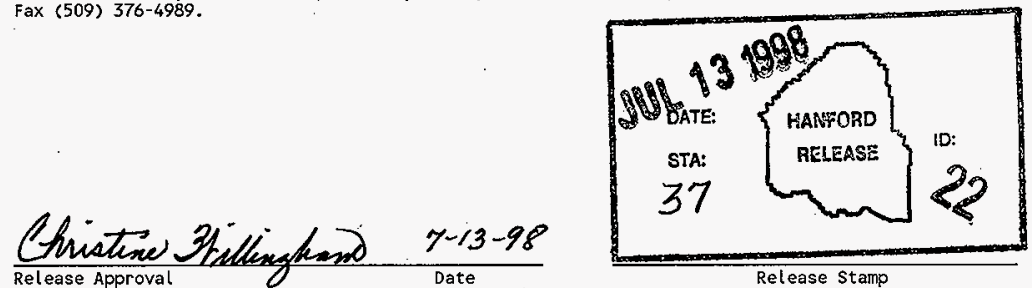

Release Stamp 
SPECIFICATION FOR MOVABLE MANIPULATOR SYSTEM

FOR USE IN RADIOCHEMICAL ENGINEER ING CELLS

HNF-2755

Rev. 0 
HNF-2755, Rev. 0

Page 2 of 11

\subsection{SCOPE}

The following are requirements for a movable manipulator system to perform work in the Airlock and B-Cell of the Radiochemical Engineering Cells (REC), 324 Building, Hanford Site. This work involves retrieval, inspection, reduction and decontamination of material on the Airlock and Cell floors, in the pipe trench and on the walls. B \& W Hanford Company (BWHC) recognizes that not all of the requirements are compatible and some may need to be changed, subject to agreement between the parties involved. BWHC also recognizes that in order to perform the tasks described two or more different machines with significantly different layout may be necessary. These requirements are the starting point for any proposa?.

\subsection{TECHNICAL REQUIREMENTS}

\subsection{Intended Uses}

A. In the REC Airlock a movable manipulator would be used to retrieve debris from the airlock floor and the pipe trench, maneuver cameras, cut debris, and decontaminate equipment and material.

B. In B-Cell a movable manipulator would be used to retrieve and cut up debris and equipment, make up and remove pipe jumpers, maneuver cameras, and decontaminate floors and walls.

C. See drawings H-3-300262, Sheet 2, Rev, 0 and H-3-300262, Sheet 6 , Rev. $O$ for Airlock and B-Cell layout. Note that these drawings are reduced reproductions of the originals and hence not to scale, and that the drawings do not show equipment and material that is in the Airlock and B-Cell. See drawing H-3-21136, Sheet 5, Rev. 1 for split plug details.

\subsection{Characteristics}

\subsubsection{Functional Characteristics}

a. Manipulator arm should be capable of 1 ifting forty pounds at full manipulator horizontal extension, sixty pounds at half extension. 
b. Desired arm sweep area (arc, range, elevation).

1) For work in the REC Airlock pipe trench, the manipulator will need to reach objects six feet below and four feet away from the manipulators position on the edge of the trench. Arm should be traversable through at least 150 degrees of arc. Arm should rotate downward through minus 60 degrees elevation.

2) For floor work a three foot reach is sufficient. The manipulator should be able to reach any point on the floor between six inches and three feet in radius. Arms should be traversable through at least 180 degrees of arc.

3) For work on walls and other equipment, presumably suspended from a crane or telescoping up the wall, a three foot radius would be sufficient. Arms should be traversable through at least 180 degrees of arc.

c. Objects to be handled.

1) Impact wrenches.

2) Hydraulic shears.

3) Electric circular and reciprocating saws.

4) Electric and pneumatic grinders.

5) Pipe jumpers.

6) Lights and video cameras.

7) Plasma arc torch.

8) Full range of the latest decontamination equipment.

d. Controls should emphasize durability and ease of operation. The design(s) should maximize the amount of equipment located outside of the hot cells. Controls should provide feedback if at all possible.

e. Cameras.

1) Two or more frame mounted video cameras with coaxial lights (cameras must be capable traversing and elevating).

2) Cameras should be located to provide stereoscopic vision. 
HNF-2755, Rev. 0

Page 4 of 11

3) Cameras will be used in conjunction with plasma arc cutting operations. The cameras should be protected against damage or loss of picture due to the bright light from the torch.

4) Other tools such as cutting devices, spray nozzles, impact wrenches may be provided by manufacturer, in place of facility equipment.

f. Power supply.

There is a 480 volt $A C, 60$ amp, weid receptacle with a local disconnect approximately 30 feet from the REC

Airlock door. An additional 480 volt AC, 60 amp, weld receptacle, a 240 volt $\mathrm{AC}, 30 \mathrm{amp}$ receptacle, and a 120 volt $A C$ breaker panel are located approximately fifty feet from the REC Airlock door.

g. Control connections.

Control and power cables linking the exterior control station and the manipulator will have pass through a $3^{\prime \prime}$ in diameter hole in the wall between the Cask Handling Area and the REC Airlock, or through 4" split plugs. The manufacturer may design their own 4" plug with integral cable and hose connections, provided it is designed with adequate shielding to protect personnel outside of the cell. In cell connections must be easy to connect and disconnect.

\subsubsection{Physical Characteristics}

a. The manipulator $p l a n$ view shadow for storage (the maximum horizontal area covered by the manipulator when not in use) needs to be minimized. Space in the REC Airlock and B-Cell on the floor is at a premium. The desired storage $\mathrm{plan}$ view shadow is six square feet. An adequate system of reactive forces will be necessary, such as outriggers or counter balance weights.

b. Physical size requirements are less stringent. The only concerns are that the movable manipulator is smal1 enough to fit through the REC Airlock and B-Cell doors, and that when deployed the movable manipulator does not interfere with movement of equipment, canisters, and debris. The REC Airlock doors are six foot wide by fifteen foot tall. The B-Cell doors are five feet wide by fifteen feet tall. 
HNF-2755, Rev. 0

Page 5 of 11

c. Equipment located out of cell should be mounted on a single cart.

d. Hydraulic pumps, compressors, transformers and other power equipment should be located outside the cell if at all possible.

\subsubsection{Reliability}

Reliability is more important than any feature or characteristic, except for storage plan view shadow size and equipment reach. The strength of the radiation field in the hot cells makes working on the movable manipulator possible only for very brief periods.

Parts shall be designed for strength and durability. Parts should also be modular for easier replacement.

The expected duty cycle for the manipulator would be twentyfive days per month, six hours per shift, three shifts per day.

\subsubsection{Maintainability}

a. Annual replacement or filtering of hydraulic fluid, lubrication of motor bearings and inspection of hoses, seals, control valves, relief valves, seals and electrical components is acceptable.

b. Equipment should be designed so that any maintenance that is required is easy to perform. Parts that will require inspection or replacement during servicing should be positioned for easy access. Connections should be watertight, but should not be difficult to make-up or disengage.

d. If hydraulic power is used, the drain reservoir should include a drain valve to control the flow out of the reservoir. The fluid level in the reservoir should be capable of being read from outside the cell or by onboard camera.

e. Limited life parts need to be replaceable. 
HNF-2755, Rev. 0

Page 6 of 11

\subsubsection{Environment}

The manipulator and any associated connections, cables, hoses and attachments that are to enter the REC Airlock or $\mathrm{B}-\mathrm{Ce} 11$ must be designed to be operable in the conditions found in these areas.

a. Equipment in the REC Airlock is exposed to $20 \mathrm{R} /$ hour. This equipment is also periodically heavily sprayed with water for decontamination purposes. Other than the previously mentioned items, the climate in the REC Airlock is relatively benign, temperature is about 65 degrees Fahrenheit. Little or no humidity is present when not performing decontamination operations, and there are no caustic or corrosive chemicals present.

b. Equipment in B-Cell is exposed to a field of up to $4,000 \mathrm{R} /$ hour. Integrated dose for the in cell equipment is estimated to be 100 million Rad. There is welding and plasma torch cutting taking place in the cell (in order to reduce the size of objects that are being discarded). The cell atmosphere will also have a lot of dust and water spray. In B-Cell the average temperature is 65 degrees Fahrenheit and there are no caustic or corrosive chemicals present.

\subsubsection{Safety}

If hydraulic fluid is used, it must be non-hazardous and non-fl ammable. The REC Airlock and B-Cell cannot have anything that is flammable. Fire loading must be limited near zero to allow welding and plasma torch cutting.

\subsection{Design and Construction}

\subsubsection{Parts/Materials/Processes}

a. Material that deteriorates in gamma fields should be minimized. Where it is used, it must be readily replaceable.

b. No lead shall be used as part of the manipulator.

c. If there are hydraulic lines, they should be covered to prevent damage from collisions with other equipment. 
HNF-2755, Rev. 0

Page 7 of 11

\subsubsection{Industry and Government Standards}

a. Electrical enclosures shall be National Electrical Manufacturer's Association Standard 250--1997, Type 4. other electrical equipment shall be designed to be repeatediy sprayed with water without failure or damage (the machine will be performing decontamination work and will be decontaminated itself prior to maintenance or repair).

b. Electrical components and wiring shall comply with the National Electric Code (NEC), Sections 240, 250, 300, $400,430,450$ and 670 .

c. Hydraulic systems shall conform to American Society of Mechanical Engineer's High Pressure Systems (HPS) Standard.

\subsubsection{Protective Coatings}

The movable manipulator surfaces shall be designed and coated as necessary to be readily decontaminated.

\subsubsection{Interchangeability}

a. If more than one machine design is used to meet these requirements, the controls, pumps, motors, actuators, valves, and as many other components as possible should be interchangeable between the two or more types of machine.

b. Within each machine every effort should be made to use common parts, i.e. the same type of relay for as many functions as possible, the same type of valve for as many functions as possible, the same type of machine screw in as many positions as possible, in order to reduce the spare parts requirements.

\subsubsection{Identification and Marking (Nameplate)}

The manipulator shall be marked with a nameplate with the following data.
a. Manufacturer's name.
b. Manufacturer's model or type number.
c. Manufacturer's serial number.
d. Manipulator voltage and current requirements. 
e. BWHC equipment I.D. number (324-MAT-MAN-1 for the first, 324-MAT-MAN-2 for the second, and so on).

f. Hydraulic fluid to be used (if hydraulic fluid is used).

\subsubsection{Document Submittal}

The following documentation shall be provided.

a. Operating and maintenance instruction manuals, electrical schematics, piping and instrumentation drawings, and equipment layout drawings will be provided to assist BWHC personnel with set-up, operation, troubleshooting and repair.

b. A list of recommended spare parts, and a list of all parts, with their cost and availability.

c. Certification that any lifting bails have been designed so that the load they must carry is less than one-third the bails yield strength.

d. Material Safety Data Sheets for any hydraulic fluid, epoxy coatings or other chemicals used.

e. A list of the base materials used for hoses and electrical wire insulation.

f. Documentation in form of catalog cuts to demonstrate enclosures are NEMA 4.

g. A list of all parts that contain or are made of polymers, their location and expected life.

h. Any shielding analysis performed.

i. A training plan for instructing BWHC personnel in operating and maintaining the mobile manipulator.

\subsection{TRAINING/TECHNICAL ASSISTANCE}

\subsection{Training}

In addition to a training plan, the manufacturer will provide a class in operating the manipulator, and a class in maintaining and repairing the manipulator. The length of each class and the material covered in it will be submitted as part of the training plan. 
HNF-2755, Rev. 0

Page 9 of 11

\subsection{Technical Assistance}

The manufacturer will provide an on site technical representative during the first calendar week of operation to provide technical assistance and additional instruction in operating and maintaining the manipulator, on an "as necessary" basis.

The manufacturer will provide a designated point of contact for BWHC personnel to consult by telephone, or electronic mail, when there are questions about operating and maintaining the manipulator.

\subsection{QUALITY ASSURANCE REQUIREMENTS}

\subsection{General}

\subsubsection{Responsibility for Verification}

The vendor will be responsible for the acceptance test portion of verification of Quality Assurance requirements. BWHC personnel will witness the acceptance tests. BWHC personnel will perform the verification inspection and review the submitted documents.

\subsubsection{Verification Methods}

Verification will be done through acceptance tests and inspection to verify the correct form/fit/function of the item, and through review of submitted documentation 1 isted in section 2.3.6.

\subsection{Inspections and Tests}

\subsubsection{Inspection}

The equipment will be inspected to verify it meets the following requirements.

a. The storage $p l a n$ view shadow will be measured to verify that it is less than six square feet.

b. The height and width will be measured to verify that the equipment will fit through a five foot wide by fifteen foot tall door.

c. Hydraulic reservoir is equipped with drain valve and easily read sight glass. 
HNF-2755, Rev. 0

Page 10 of 11

d. Manipulator has nameplate with data listed in section 2.3.5.

\subsubsection{Acceptance test}

The following actions will be performed.

a. The manipulator will be picked up by it's lifting bail.

b. The full function of the manipulator arm will be demonstrated.

1) The manipulator grip will be operated.

2) The manipulator arm will lift forty pounds at full horizontal extension and sixty pounds at half full horizontal extension.

3) The manipulator arm will be traversed, elevated and extended/retracted through it's full range of motion. Traverse, elevation and extension will be measured to verify they meet function characteristics listed in section 2.2.1.

c. Each camera will be operated and the full range of traverse, elevation and zoom will be demonstrated to verify that it is in working order.

d. Each light will be operated to verify that it is in working order.

e. Demonstrate parts replacement per the operating and maintenance manual.

\subsection{PREPARATION FOR DELIVERY}

\subsection{General}

Boxes and crates will be marked on the outside to facilitate identification of purchase order, package contents, special handling instructions and destination. The movable manipulator and it's associated support equipment will be shipped to Babcock and Wilcox Hanford Company, care of Central Receiving, 2355 Stevens Drive, Richland, Washington. The shipment shall be F.O.B. Richl and, Washington. 
HNF-2755, Rev. 0 Page 11 of 11

\subsection{Preservation and Packaging}

A. Equipment will need to be lubricated in accordance with operating and maintenance instruction manual prior to packaging.

B. Equipment and materials will be boxed or crated in a manner to prevent damage during shipment. Suitable packing material and dunnage will be included inside of boxes and crates to prevent equipment from shifting around inside of boxes and crates. Boxes and crates will be securely fastened down during shipping.

\subsection{Other}

A. Photos should be taken of materials in crates and boxes prior to seajing to document equipment condition and proper packaging. Additional photos should be taken of boxes and crates once they are strapped down on truck, if possible.

B. BWHC should be notified when material is shipped.

C. BWHC will inspect equipment and material upon arrival for signs of damage and will inform the manufacturer if any is found. 